ISSN 2305-2678 (Print); ISSN 2305-5944 (Online)

DOI : http://dx.doi.org/10.4314/rj.v28i1.2

\title{
Rabbit droppings as an organic fertilizer in earthen ponds, to improve growth and production of Nile tilapia, Oreochromis niloticus L., in Rwanda.
}

${ }^{* 1.3}$ Simon Rukera Tabaro, ${ }^{1}$ Onisimo Mutanga, ${ }^{1}$ Denis Rugege, and ${ }^{2}$ Jean-Claude Micha ${ }^{1}$

\begin{abstract}
$\underline{\text { Abstract }}$
Nine earthen ponds of $400 \mathrm{~m}^{2}$ were stocked with mixed sexes of Nile tilapia Oreochromis niloticus (LINNE, 1757) fingerlings of $14 \mathrm{~g}$ mean weight at a density of $2 \mathrm{fish} / \mathrm{m}^{2}$ and fertilized with fresh dung dropped directly from rabbits stocked at three different densities: T1: 1 rabbit/are; T2: 2 rabbits/are and T4: 4 rabbits/are (lare $=100 \mathrm{~m}^{2}$ surface area) of pond in hutches suspended above the ponds. After a culture period of 140 days, an increasing pattern in all nutrients was observed in the three treatments with only nitrates decreasing with time in all treatments. However, lower concentrations of total nitrogen (TN) were recorded within ponds receiving droppings from the highest stocking rate of rabbit (T4) but the difference between treatments was not significant $(P<0.05)$. In addition, similar trends in decreases over time were observed for water transparency, dissolved oxygen (1.41 $-10.48 \mathrm{mg} / \mathrm{l})$ and water daily primary productivity $\left(178.01-426.82 \mathrm{mg} \mathrm{C.} \mathrm{m}^{-2} . \mathrm{d}^{-1}\right)$. Temperature was higher during the rainy season $\left(20.6-27.8^{\circ} \mathrm{C}\right)$ than in the dry season $\left(19.6-24.4^{\circ} \mathrm{C}\right)$ with significantly higher afternoon $\mathrm{pH}$ compared to the morning. Fish masses at harvest and fish net-production were higher in ponds fertilized by the largest number of rabbits (T4: $42.32 \mathrm{~g} \& 18.38 \mathrm{~kg} \cdot \mathrm{are}^{-1} \cdot \mathrm{yr}^{-1}$ ).

This study showed that the rearing of rabbits over fish ponds establishes a better environment for fish (O. niloticus) and offers superior hygiene conditions for rabbit production. Although the largest number of rabbits resulted in the best water quality for O.niloticus production, it is urged that the rabbit load-rate be optimized in order to obtain a sustainable system of rabbit and fish production.
\end{abstract}

Keywords: Rabbit droppings, fish pond water quality, fish growth and production, rabbit densities

1 1-University of KwaZulu-Natal/ South Africa, 2-University of Namur/ Belgium, 3-National University of Rwanda/ Rwanda 


\section{INTRODUCTION}

Rwandan agriculture and livestock keeping employs over $90 \%$ of the Rwandan labour force but the food and nutritional needs of the population are still characterized by a high level of malnutrition. Like most parts of sub-Saharan Africa, Rwanda faces increasing pressures on natural resources due to the rapid increase in population and the continuing increase in the standard of living (Kapetsky, 1994). In Rwanda, the high population density $\left(>300\right.$ inhabitant $\left./ \mathrm{km}^{2}\right)$ and the high rate of demographic increase $(2.84 \%)$ exceeds the increase in the rate of agricultural production $(2.2 \%)$ (MINECOFIN, 2002). Agriculture is still unable to contribute substantially to the economy of the country as it is of a mainly subsistence nature. To address this, Rwanda has ranked by importance six broadly identified areas through which it will act on a priority basis. Rural development and agricultural transformation have been identified as the first important areas to be improved upon (MINECOFIN, 2002). Strategies for the agricultural sector include increasing rural incomes, enhancing food security, and transforming agriculture by moving from subsistence to market-based activities.

This study aimed at contributing to these goals by optimising an integrated agro-ecosystem which seeks to contribute substantially to Rwandans' nutritional needs while increasing income. The envisaged system is composed of four fully-integrated levels of production: the rabbit - fish crop integrated system. This first study has been conducted on two levels of the system with the objectives of clarifying rabbits' adaptation to wetland, the effect of rabbit dung on the quality of fish pond water, and the growth and production performances of Nile tilapia in this environment.

Fish is nutritionally important and provides $20 \%$ or more of the animalprotein intake of the majority of the population of sub-Saharan Africa (van Dam et al., 2006). Fish production in Rwanda's ponds is dominated by Nile tilapia (Oreochromis niloticus LINNE 1757) monoculture and in polyculture with African catfish, (Clarias gariepinus, BURCELL 1822) where catfish fingerlings are available. Fish farming is undertaken in individual and cooperative fishponds that are sometimes integrated with crop production and to a lesser extent with livestock production. Ponds are fed occasionally and fertilized using different types of grass compost cut from the pond dikes 
and with very small amounts of animal manure produced on hills near homesteads where animals are kept (Micha, 2001).

In Rwanda, especially in rural areas, rabbit husbandry is a common and easily practiced food-production activity for people in almost all livelihoods. Smallholder farmers who cannot afford the farming of large livestock have became particularly interested in rabbit farming for both profit and subsistence, mainly due to the high fecundity and short production cycle of rabbits; both characteristics being associated with low investment- and production-costs. Research on integrated rabbit-aquaculture is, however, very limited mainly due to the fact that climactic conditions for rabbit production do not match those for aquaculture in a natural environment. Preliminary results obtained in Cameroon pointed to the promising effect of rabbit manure as a water fertilizer for Oreochromis niloticus ponds and as a food-source for the catfish Heterobranchus longifilis (Breine et al., 1995). (Franco, 1991), using dried rabbit dung to feed tilapia O. niloticus in mesocosms, reported that the fish did not eat the fecal pellets of adult rabbits but did consume the fecal pellets voided by weanling and kid rabbits, which tempts to suggest that $O$. niloticus could be attracted by the milk residuals and derivatives found in pellets voided by young rabbits. Direct integration rabbit-fish production (rearing rabbits over fish ponds) was tried for the first time in Rwanda in 1988 by researchers of the National Fish Culture Service (SPN) at Kigembe (Southern province). Van Vleet (1991) reported similar fish yields $(6,000 \mathrm{~kg} / \mathrm{ha})$ to those obtained from integrated fish cum chicken production systems $(6,500 \mathrm{~kg} / \mathrm{ha})$ and even better results than yields from integration with pigs $(5,000 \mathrm{~kg} / \mathrm{ha})$ and ducks $(4,500 \mathrm{~kg} / \mathrm{ha})$ in the same fish farm. The author recommended, for extension purposes, a load-rate of 60 rabbits per fish pond of four area surface, but fish could fed from rabbit, chicken, or ducks' pellets that fell into ponds which was not possible when rabbits are fed forages. However, the author did not make any observation on the impact of rabbits on the quality of water over the rearing time.

Integrated rabbit-fish farming thus works on the principle that fertilized water develops a marked quantity of phytoplankton and zooplankton; the natural food-source of one of the main fish species produced in aquaculture - the Nile tilapia, O. niloticus. The integration is of interest to agricultural ecologists and aqua-culturists as it constitutes a means of sustaining system productivity and mitigating the negative environmental impact of aquaculture effluents. 
It is with the same objective that the present study has been undertaken, i.e. to fully investigate the use of wastes/by-products at multiple levels of production, namely the Integrated Rabbit-Fish-Rice System. It compares well with the Integrated Aquaculture/Agriculture System that is capable of predicting fish growth and production, simulating crop biomass growth, soil organic matter and nitrogen concentrations based on waste recycling processes (Jamu and Piedrahita, 2002). Furthermore, it is fortunate that rabbit excrement contains several nutrients and also acts as a source of digestible energy. Rabbit manure is a rich source of inorganic nitrogen, phosphorus, cellulose, and lignin (Franco, 1991, Kumar and Ayyapan, 1998) which are important from the aquaculture point of view, particularly inorganic nitrogen and phosphorus which are readily utilized by phytoplankton to fuel growth. (McCrosckey, 2001) reported that rabbit droppings have about 3-1.5-0.3 of N-P-K and according to (Lebas et al., 1996), rabbit manure is much richer in nutrients than ordinary farm manure which typically contains $0.4 \%$ to $0.6 \%$ nitrogen while rabbit dung contains up to $2.4 \%$ nitrogen (Table 1 ).

Table 1: Approximate N, P and $\mathrm{K}$ values of animal manure

\begin{tabular}{llll}
\hline Animal & $\begin{array}{l}\text { Nitrogen } \\
(\mathbf{\%})\end{array}$ & $\begin{array}{l}\text { Phosphoric } \\
\text { acid (\%) }\end{array}$ & $\begin{array}{l}\text { Potash } \\
\mathbf{( \% )}\end{array}$ \\
\hline Dairy cow & 0.57 & 0.23 & 0.62 \\
Beef steer & 0.73 & 0.48 & 0.55 \\
Horse & 0.7 & 0.25 & 0.77 \\
Swine & 0.49 & 0.34 & 0.47 \\
Sheep/goat & 1.44 & 0.5 & 1.21 \\
Chicken & 1 & 0.8 & 0.39 \\
Rabbit & $\mathbf{2 . 4}$ & $\mathbf{1 . 4}$ & $\mathbf{0 . 6}$ \\
\hline
\end{tabular}

Source: Lebas et al. (1996)

Preliminary results obtained from rabbit-fish integration (Breine et al., 1996, Franco, 1991) report that rabbit dung application in ponds increases phytoplankton abundance, indicating that it has a notable impact on primary production. During his study on the effect of rabbit dung on the growth of Oreochromis niloticus, (Breine et al., 1996) observed a fish growth-rate that was 5.1 times that of the control group. 
Rabbit dung has also been used successfully in integrated aquaculturebiogas production. Bio-digester effluent, after rabbit dung decomposition, has been used as organic fertilizer in fish ponds from which (Mahadevaswamy and Venkataraman, 1988) reported good yields $\left(8.9 \mathrm{~kg} / 100 \mathrm{~m}^{3} / 120\right.$ days), favorable colour, flavour and taste for the common carp (Cyprinus carpio) and major carp (Labeo rohita). This study is a start of part of a broad research programme to investigate the potential of the integration of agriculture and aquaculture which includes rabbits, while protecting the environment in Rwanda. It focuses on the effects of rabbit droppings on fish pond water-quality and consequently on the growth and production of a species of filter feeder fish, the Nile tilapia (Oreochromis niloticus).

\section{MATERIALS AND METHODS}

Domestic rabbits are stated to have the adaptability to exist, on a wide and varied diet, in conditions ranging from tropical to arctic. Research has shown that climate can affect rabbit performance (Fayez et al., 1994, Lebas et al., 1996, Yamani and Farghally, 1994). The present study was conducted on rabbits reared at the Rwasave Fish Farming Research Station, National University of Rwanda, Butare, Rwanda (geographic coordinates: $2^{\circ} 40^{\prime} \mathrm{S}$ and $29^{\circ} 45^{\prime} \mathrm{E}$ ) in conditions described as follows: average annual temperature 14 - $28{ }^{\circ} \mathrm{C}$, monthly relative humidity $59-83 \%$, which includes "the comfort zone" of $21{ }^{\circ} \mathrm{C}$ temperature and 60 to $65 \%$ humidity level (Fayez et al., 1994, Lebas et al., 1996). Note that Rwasave marshland was subject to frequent fluctuations that can sometimes lower the temperature to below 12 ${ }^{\circ} \mathrm{C}$ or increase rabbit hutch temperature to above $35{ }^{\circ} \mathrm{C}$. This compromises both rabbit growth-performance and fish production in ponds fed with local grass cut only in the area surrounding the fish ponds.

The experiments were conducted between March $20^{\text {th }}$ and August $19^{\text {th }} 2008$ in nine earthen ponds (size: $400 \mathrm{~m}^{2}$, maximum water depth: $110 \mathrm{~cm}$ ). Rabbits were reared in hutches suspended over fish ponds, were fed only local grass cut in the area surrounding the fish ponds and received water $a d$ libitum. All rabbits were weighed fortnightly to monitor their growth and were regularly checked for any diseases that could occur during the period of the experiment. Fish ponds were first drained, dredged, dried and then refilled with water from an alimentation canal. Additional water was sometimes supplied to compensate for losses from evaporation and seepage. 
Three treatments were assigned randomly in triplicate ponds $\left(400 \mathrm{~m}^{2}\right.$ surface area) fertilized with rabbit droppings falling directly from 1, 2, and 4 rabbits per are of pond, being treatments T1, T2, and T4. Each pond was stocked with fingerlings of mixed sex Nile tilapia (O. niloticus) (average weight: $14.9 \mathrm{~g}$ ) at a density of 2 fish per $\mathrm{m}^{2}$. No supplementary feed was given to the fish during this experiment.

\subsection{Physico-chemical parameters of fishpond water}

Temperature $\left({ }^{\circ} \mathrm{C}\right.$ ), electrical conductivity (WTW LF 38/set), pH (WTW $\mathrm{pH} 320 /$ set 2), dissolved oxygen (WTW oxi 325/set), and water transparency in meters (Secchi disk) were measured every two weeks between 07:00 and 08:00 am directly into ponds at both surface- $( \pm 10 \mathrm{~cm}$ below the surface $)$ and bottom- $( \pm 85 \mathrm{~cm}$ depth) layers. At the same time, a Van Doorn water sampler was used to collect water for analysis at two different depths; surface and at $70 \mathrm{~cm}$ depth in the middle of each pond. Collected samples were mixed and kept at $4{ }^{\circ} \mathrm{C}$ until analysis, except for Ammonia-nitrogen and Total Kjeldhal Nitrogen which were analysed immediately after sampling. Ammonia analysis was made using the titrimetric method after distillation (Descy, 1989), nitrates nitrogen were analysed by the spectrophotometric method after digestion with phenoldisulfonic acid (Boyd, 1979), and Nitrites were analysed using Standard Methods (Franson et al., 1985). Total nitrogen was analysed by the Kjeldahl method (Léonard and Kanangire, 1998). Orthophosphates (soluble reactive phosphorus) were analysed by using the ascorbic acid method (Golterman et al., 1978 adapted by (Descy, 1989), while total phosphorus was determined by persulfate digestion (Léonard and Kanangire, 1998). Total alkalinity was determined using the titrimetric method (Descy, 1989).

\subsection{Primary production in fish ponds}

Fish ponds' primary productivity was determined through the measurement of dissolved oxygen, using an oxymeter (WTW oxi 325/set), in order to ascertain levels of oxygen produced by primary producers into ponds. Oxygen concentrations were then measured at different depths and produced oxygen as well as consumed oxygen by respiration, were recorded after incubation of light and dark bottles to finally calculate the Net and Gross productions. Daily productivity was determined using a Photosynthesis simulator PSS 2000 version 2.1 (Dauta and Capblancq, 1999). 


\subsection{Fish growth and production}

35 fish per pond were sampled randomly every 2 weeks during a period of 127 days. Individual fish biomass was measured using an electronic balance (Mettler balance, accuracy: 0.01g). On each occasion, the fish were returned to their corresponding ponds. 127 days after stocking, the ponds were completely drained and the fish were harvested, counted and weighed to the nearest gram. Fish data at stocking and harvest were used to calculate: the survival rate SR $(\%)=100-[100 .(\mathrm{N} 1-\mathrm{N} 2) / \mathrm{N} 1]$, the specific growth rate SGR $\left(\% \cdot d^{-1}\right)=100 *((\ln W 2-\ln \mathrm{W} 1) / \mathrm{d} 2-\mathrm{d} 1)$, and the daily weight gain DWG $\left(\right.$ g. $\left.\mathrm{d}^{-1}\right)=(\mathrm{W} 2-\mathrm{W} 1) /(\mathrm{d} 2-\mathrm{d} 1)$ where $\mathrm{N}=\Delta \mathrm{t}$ (the rearing time in days). The net production $\left(\mathrm{kg} \cdot \mathrm{are}^{-1} \cdot \mathrm{year}^{-1}\right)$ as well as the Yield (kg/are) were also calculated.

At initial fish stocking and final harvest, $10 \%$ of the fish were weighed individually using an electronic balance (Mettler balance, accuracy: 0.01g). A scale mounted on a measuring board was used to measure the fish totallength. The total bulk weight of fish stocked into each pond was taken using a weighing scale and recorded and the assignment of fish to the ponds was done randomly, care being taken to ensure that equal numbers and almost equal biomass were stocked in each pond.

At harvest, all ponds were drained completely and the total bulk weight and number collected from each pond were recorded. This allowed for calculation of the overall survival, the specific growth rate (SGR, \% body weight per day), the daily weight gain (DWG g.d $\mathrm{d}^{-1}$ ), and the net fish yield (NFY Kg. $\mathrm{a}^{-1} \cdot \mathrm{y}^{-1}$ ) for each pond. Specific growth rate was estimated as SGR $=\left[\left(\ln _{\mathrm{t}}-\mathrm{InW}_{\mathrm{o}}\right) \times 100 \mathrm{t}^{-1}\right]$; the net fish yield (NFY) was calculated as NFY

$=$ [total biomass of fish at harvest - total biomass of fish at stocking], with extrapolation of yield on a year rearing-period considered per are of ponds (Azim et al., 2002). Fish survival rate (SR), SR = fish number at harvest/fish number at stocking) $* 100$ was also calculated.

\subsection{Statistical data analysis}

All data were encoded into Microsoft Excel worksheets which were imported using "GENSTAT 12th edition "software for statistical analysis. Data for plankton abundance and quality were directly used to draw graphs, showing the differences among ponds and treatments but no statistical analysis was applied because data were not taken from all nor replicated at every sampling day. 
For water quality parameters, including primary productivity in the experiment, analysis of variance (ANOVA) for repeated measurements was used. The validity of data was checked with the least significant difference of means (LSD) and was used to check significances at 5\% level. One-way ANOVA was used for fish growth parameters like SGR, DWG, productivity and yield, rabbit biomass, and survival rate (SR).

\section{RESULTS}

\subsection{Rabbit growth and survival}

The rabbit average body weight increased significantly in all treatments, moving from about 500 to almost $2000 \mathrm{~g}$. However, treatment T1 with 1 rabbit per one square metre hutch showed significantly higher weight growth (table 2 and Figures 1) than treatments $\mathrm{T} 2$ and T4, which were not significantly different from each other.

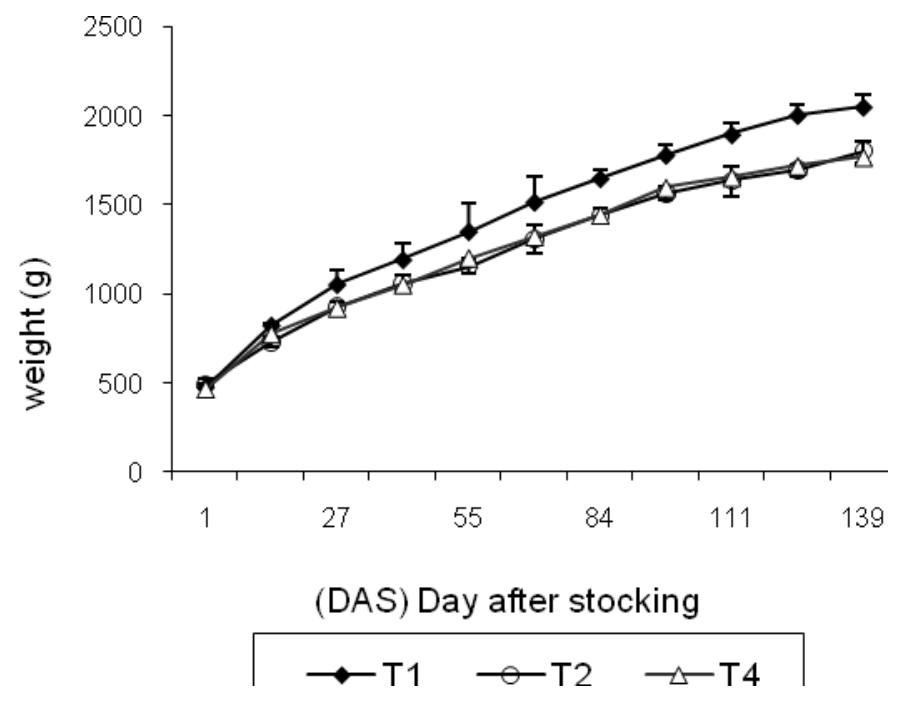

Figure 1: Rabbit weight gain when reared over fish ponds for 140 days at 1 , 2 and 4 rabbits per square metre hutch.

The average daily weight gain (DWG) $\left(\right.$ g.day $\left.^{-1}\right)$ and the specific growth rate $\left(\right.$ SGR \%.day ${ }^{-1}$ d) were statistically different between treatments (Table 2). Rabbits in T1 gained 11.39 g.day $^{-1}$ while rabbits in T2 and T4 were gaining

Rwanda Journal ISSN 2305-2678 Volume 28, Series E, 2012 : Agricultural Sciences 
a daily weight averaging 9 g.day ${ }^{-1}$. Likewise, T1 was characterized by a SGR significantly higher than those for $\mathrm{T} 2$ and $\mathrm{T} 4$, the latter two treatments not being statistically different from each other.

Table 2: Specific Growth Rate (SGR \%.day ${ }^{-1}$ ), Daily Weight Gain (DWG

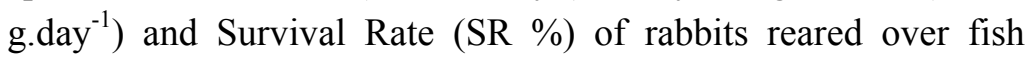
ponds in Rwasave wetland (south Rwanda) for 140 days

\begin{tabular}{lllll}
\hline Treatments & Mean weight & ${\text { SGR }\left(\% . \text { day }^{-1}\right)}^{-1}$ & DWG $\left(\right.$ g.day $\left.^{-1}\right)$ & SR $(\%)$ \\
\hline T1 & $2049.63 \pm 67.83^{\mathrm{a}}$ & $1.05 \pm 0.03^{\mathrm{a}}$ & $11.39 \pm 0.42^{\mathrm{a}}$ & $100 \pm 0.00^{\mathrm{a}}$ \\
T2 & $1799.22 \pm 60.46^{\mathrm{b}}$ & $0.94 \pm 0.05^{\mathrm{b}}$ & $9.47 \pm 0.46^{\mathrm{b}}$ & $95.8 \pm 7.21^{\mathrm{a}}$ \\
T4 & $1767.66 \pm 16.48^{\mathrm{b}}$ & $0.97 \pm 0.03^{\mathrm{b}}$ & $9.43 \pm 0.22^{\mathrm{c}}$ & $95.8 \pm 7.22^{\mathrm{a}}$ \\
LSD (5\% level) & $80.33^{* *}$ & $0.081^{*}$ & $0.038^{* *}$ & $\mathrm{NS} \mathrm{P}=0.45>0.05$ \\
\hline
\end{tabular}

Numbers in the same column with the same superscript letter are not significantly different at $5 \%$ level of probability; $\quad \mathrm{NS}=$ non significant difference among treatments, $*=$ significant difference, $* *=$ highly significant difference.

\subsection{Rabbit droppings and the dynamic of nitrogen and phosphorus nutrients in ponds}

Important biogenic parameters that are of interest in this study, were nitrogen and phosphorus forms, as they influence the pond's primary production and consequently the filter fish feeders like Nile tilapia. The dynamics of a fish pond lie in the variations of not only nutrient (biogenic elements) concentrations but also of physico-chemical parameters (temperature, dissolved oxygen, $\mathrm{pH}$, salinity etc.). In general and for each treatment, the trend of the parameter variation was drawn using data collected either every two weeks, twice (start and end of experiment) or three times (beginning, middle, and end of experiment).

This study focused on the effect of rabbit dung on the quality of the pond (water and fish). Table 5 shows general mean values of physico-chemical parameters measured daily - twice or thrice per day - as well as minimum and maximum means calculated on replications for each treatment. Globally, the highest temperature, $\mathrm{pH}$ and conductivity were observed in the treatment with 4 rabbits per are of pond (T4) as the source of fertilization. These ponds had lower values, but not significantly, on dissolved oxygen, primary production and water transparency. Detailed data are presented and discussed below in this study. 


\section{Nitrogen nutrients}

Assessed nutrients of nitrogen forms in fishpond water were: ammonium $\left(\mathrm{N}-\mathrm{NH}_{4}\right)$, nitrites $\left(\mathrm{N}-\mathrm{NO}_{2}\right)$, nitrates $\left(\mathrm{N}-\mathrm{NO}_{3}\right)$, and total nitrogen $(\mathrm{TN})$. Similar trends of significant increase were shown by all these nutrients except for nitrates, which increased during the first month (Figure 2) of the experiment and decreased thereafter.

Table 3: Means with standard errors for nutrients in water obtained from three different rabbit-stocking rates: 1, 2 and 4 per are of pond. Samples were a mixture of water from the surface and bottom layers of the pond.

\begin{tabular}{|c|c|c|c|}
\hline \multirow[t]{2}{*}{ Nutrients } & \multicolumn{3}{|r|}{ Treatments } \\
\hline & T1 & $\mathbf{T} 2$ & T4 \\
\hline 1. Total nitrogen $\left(\mathrm{mg} . \mathrm{L}^{-1}\right)$ & $13.52 \pm 0.39^{\mathrm{a}}$ & $13.19 \pm 1.53^{\mathrm{a}}$ & $12.45 \pm 0.91^{\mathrm{a}} \mathrm{ns}$ \\
\hline 2. Nitrates-nitrogen (mg. $\left.\mathrm{L}^{-1}\right)$ & $0.75 \pm 0.51$ & $1.46 \pm 0.43$ & $2.72 \pm 0.71 \quad \mathrm{~b} * *$ \\
\hline 3. Ammonia-nitrogen $\left(\mathrm{mg} . \mathrm{L}^{-1}\right)$ & $0.44 \pm 0.30$ & $0.51 \pm 0.31$ & $0.69 \pm 0.41 \quad b * *$ \\
\hline 4. Nitrites-nitrogen (mg.L $\left.{ }^{-1}\right)$ & $0.40 \pm 0.09$ a & $0.50 \pm 0.12 \quad$ a & $0.69 \pm 0.10^{\mathrm{b} * *}$ \\
\hline 5. Total phosphorus (mg. $\left.\mathrm{L}^{-1}\right)$ & $0.62 \pm 0.11$ & $0.69 \pm 0.12$ & $0.94 \pm 0.10^{\mathrm{b} *}$ \\
\hline 6. Ortho-phosphates (mg. $\left.\mathrm{L}^{-1}\right)$ & $0.07 \pm 0.02^{a}$ & $0.10 \pm 0.02^{\mathrm{a}}$ & $0.21 \pm 0.07^{\mathrm{b} * *}$ \\
\hline
\end{tabular}

All data are means \pm standard deviation of data collected on 3 replicates during the entire period of the experiment. Data that have the same superscript letters in the same row are not significantly different (ns). ${ }^{*}$ ) different at $\mathrm{P}<0.05$ and $(* *)$ different at $\mathrm{P}<0.01$.

Total nitrogen $(\mathrm{TN})$ concentration increased in direct relation with time of manuring. It was observed that $\mathrm{TN}$ concentration in fishpond water had the same pattern as that of nitrites and ammonia-nitrogen relative to rearing time $(\mathrm{P}<0.001)$, but treatments didn't differ significantly $(\mathrm{P}=0.115)$ among them (Figure 2).

Contrary to other nitrogen forms, nitrate concentrations decreased over time showing high values in mid-term of the experiment (Figure 2.D) especially in T2 and T4. Nitrate concentration values were $0.75 \pm 0.51,1.46 \pm 0.43$, and $2.72 \pm 0.60 \mathrm{mg} / 1$ respectively for $\mathrm{T} 1, \mathrm{~T} 2$, and $\mathrm{T} 4$. Treatment $\mathrm{T} 4 \mathrm{had}$ significantly higher concentrations of nitrates-nitrogen $(\mathrm{P}<0.001)$, while no statistical difference was evident between $\mathrm{T} 1$ and $\mathrm{T} 2$ concentrations (Table 3).

Ammonia (Figure 2.B and table 3) increased with time in all treatments that showed statistical differences between them. Treatment with higher numbers of rabbits $(\mathrm{T} 4)$ had a significantly higher $(\mathrm{P}<0.001)$ ammonia concentration than $\mathrm{T} 2$ and $\mathrm{T} 1$ treatments, among which ammonia concentrations were not significantly different $(\mathrm{P}>0.05)$. Mean ammonia concentrations, in 
ensemble, were ranged between $0.33 \pm 0.2 \mathrm{mg} / \mathrm{l}$ and $1.07 \pm 0.5 \mathrm{mg} / \mathrm{l}$ obtained in $\mathrm{T} 4$ at the end of experiment.

Concentrations of nitrites (Figure 2.C) and ammonia are the nitrogen forms that can escalate to toxic levels due to accumulation in organic matter in fishponds (Losordo, 1997). Nitrites were significantly higher $(\mathrm{P}<0.001)$ in ponds treated with 4 rabbits per are $\left(100 \mathrm{~m}^{2}\right)$. Mean nitrite concentrations were $0.70 \pm 0.10 \mathrm{mg} / 1$ in $\mathrm{T} 4$, while concentrations were $0.40 \pm 0.09 \mathrm{mg} / 1$ and $0.50 \pm 0.12 \mathrm{mg} / 1$ in $\mathrm{T} 1$ and $\mathrm{T} 2$, respectively (Table 3 ).

\section{Phosphorus nutrients}

Phosphorus nutrients were analysed in water samples in 2 forms: total phosphorus (TP) and soluble reactive phosphorus (SRP) or orthophosphate. During the present study, the two forms of phosphorus increased significantly over time $(\mathrm{P}<0.001)$ in all treatments but the treatment $\mathrm{T} 4$ showed significantly higher concentrations of SRP $(\mathrm{P}<0.01)$ and significant concentrations of TP $(\mathrm{P}<0.05)$.

Mean TP concentration values were $0.62 \pm 0.11,0.69 \pm 0.12$, and $0.94 \pm 0.10$ $\mathrm{mg} / 1$ respectively in $\mathrm{T} 1, \mathrm{~T} 2$ and $\mathrm{T} 4$, while values of $0.07 \pm 0.02,0.10 \pm 0.02$, and $0.21 \pm 0.07 \mathrm{mg} / 1$ of SRP respectively in $\mathrm{T} 1, \mathrm{~T} 2$, and $\mathrm{T} 4$ treatments (Figure 2.E\&F) were found. 

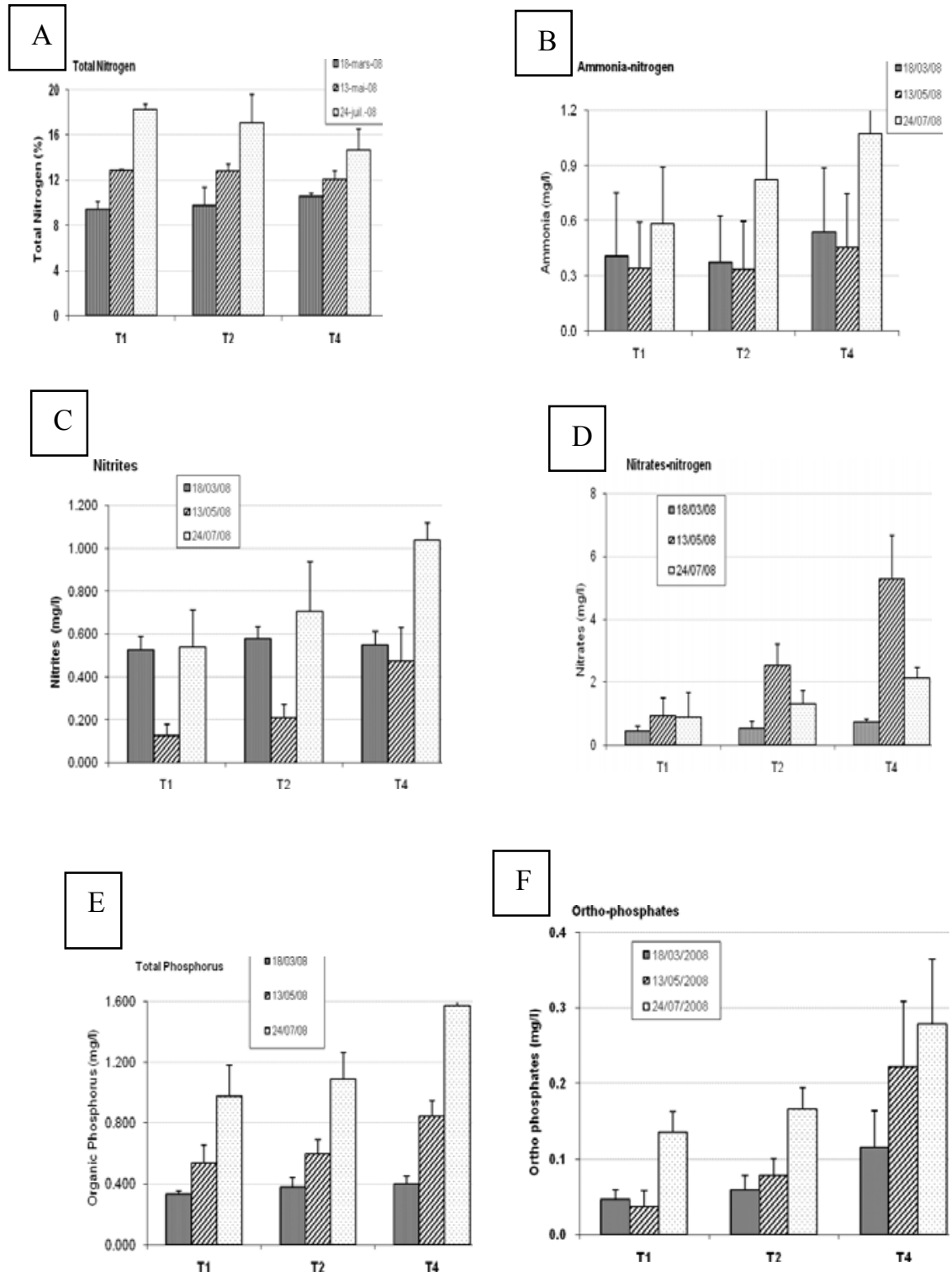

Figure 2. Showing concentrations for nutrient nitrogen[A,B,C \& D] and phosphorus [E, F] forms in Nile tilapia (O. niloticus) ponds, fertilized by rabbit droppings for nearly 5 months. 


\subsection{Fish growth and production performances in an integrated rabbit-fish system}

Mean fish-weight of the Nile tilapia (O. niloticus) was not significantly different among treatments $(\mathrm{P}<0.05)$ at the end of the experiment. Regression made for rearing days and fish weight showed that treatments explained the variance in fish-weight increase for $91.9 \%$, the weight in all treatments increased significantly $(\mathrm{P}=0.003,0.001$ and 0.000$)$ respectively for $\mathrm{T} 1, \mathrm{~T} 2$, and T4. The steepest slope was presented by $\mathrm{T} 4$ as the regression equation displays $\mathrm{Y}=-78.71+0.21 \mathrm{~T} 1+0.37 \mathrm{~T} 2+0.46 \mathrm{~T} 4$ and data presented in Table 4 and Figure 3.

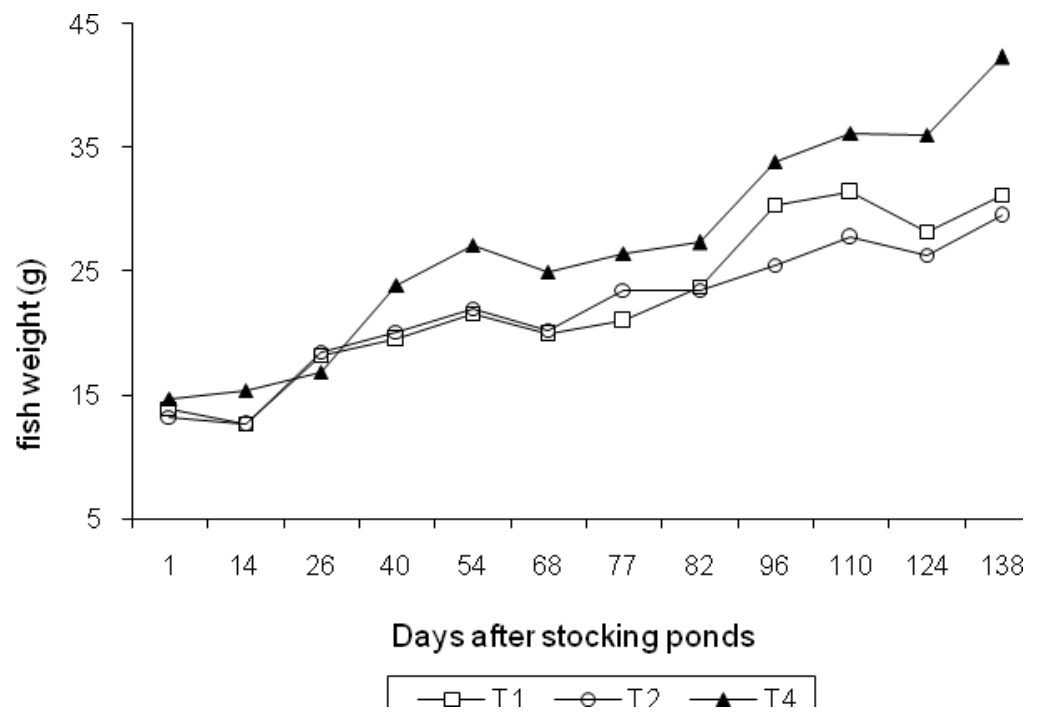

Figure 3: Trends in mean weight of Nile tilapia (O. niloticus) reared in earthen ponds fertilized by 1,2 and 4 rabbits per are of pond for nearly five months.

Yield and net fish production were high in general $\left(4.61-6.35 \mathrm{~kg}\right.$. are $^{-1}$ for yield and between 11.34 and $18.38 \mathrm{~kg} \cdot \mathrm{are}^{-1} \cdot \mathrm{year}^{-1}$ for fish production). The treatment that received droppings from $\mathrm{T} 4$ was higher $(\mathrm{P}<0.05)$ in terms of fish productivity than $\mathrm{T} 1$ and $\mathrm{T} 2$ (Table 4 Figure 4 . A\&B). Fish growth was assessed through the daily weight gain (DWG in g.day ${ }^{-1}$ ), the specific growth rate (SRP in \%.day ${ }^{-1}$ ) and the survival rate $(\mathrm{SR})$ in all treatments. 
The mean DWG was low in all treatments, which ranged from 0.10 to 0.15 g. day $^{-1}$ but the SR (\%) was high $(79.82-93.3 \%)$ with no significant difference among treatments for both DWG and SR. Nevertheless, the highest value was always present in T4 (Table 4).
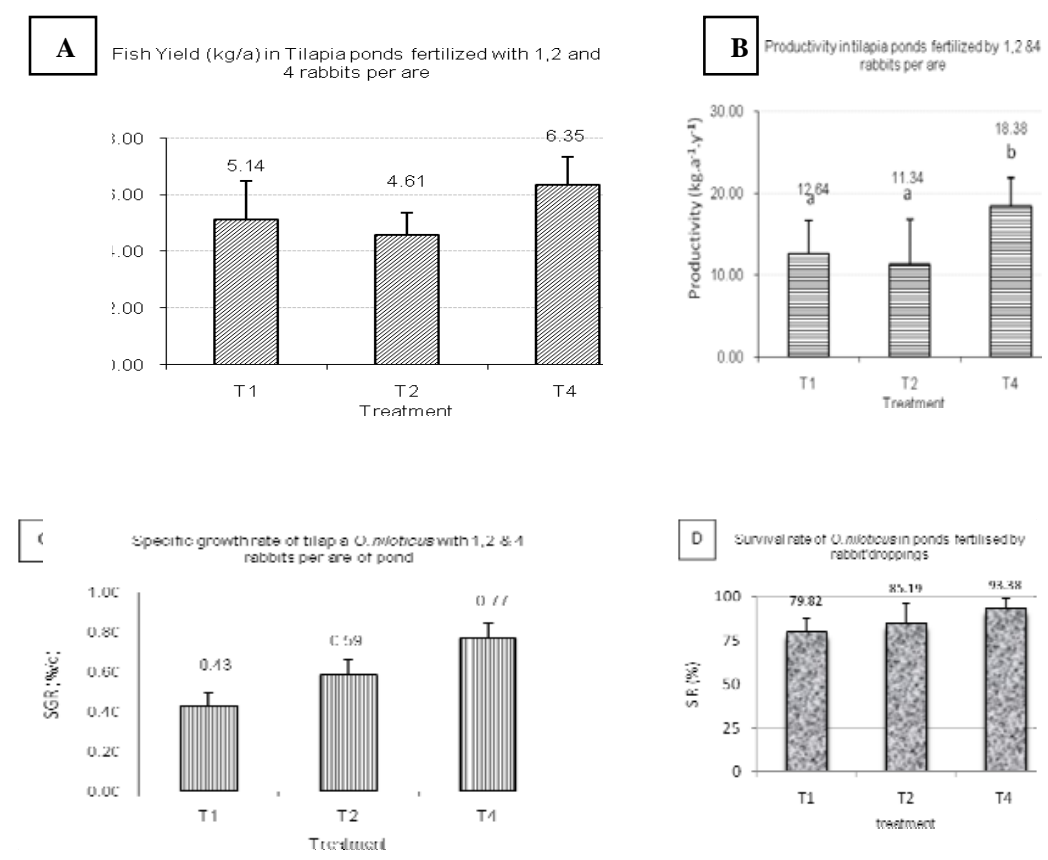

Figure 4: A. Fish yield $\left(\mathrm{kg} \cdot \mathrm{a}^{-1}\right)$, B. Production $\left(\mathrm{kg} \cdot \mathrm{a}^{-1} \cdot \mathrm{y}^{-1}\right)$, C. Specific growth rate $\left(\%\right.$ day $\left.^{-1}\right)$ and $\mathbf{D}$. Survival rate (\%) of Nile tilapia (Oreochromis niloticus) reared in ponds fertilized by 1,2 and 4 rabbits per are of pond. $\left(\mathrm{kg} \cdot \mathrm{a}^{-1}=\right.$ kilogram per are $\left(100 \mathrm{~m}^{2}\right),\left(\mathrm{kg} \cdot \mathrm{a}^{-1} \cdot \mathrm{y}^{-1}=\right.$ kilogram per are per year $)$.

On the other hand, treatments were all significantly different $(\mathrm{P}<0.05)$ for SGR. Treatment $\mathrm{T} 4$ was significantly higher $(\mathrm{P}<0.001)$ than the others following this order: T4 $>$ T2 $>$ T1 with relatively low mean values $0.77>0.59>0.43 \%$.day ${ }^{-1}$ (Figure 4.C Table 4). 
Table 4: Growth and Production performance of Nile tilapia (O. niloticus) reared in earthen ponds fertilized by rabbit dung at three different densities for nearly five months

Pond stocking time

\begin{tabular}{llll}
\hline Treatment & Number of fish & Mean weight $(\mathbf{g})$ & Biomass $(\mathbf{k g})$ \\
\hline T1 & 707 & $13.93 \pm 0.8$ & 9.84 \\
T2 & 753 & $13.24 \pm 1.0$ & 9.97 \\
T4 & 800 & $14.74 \pm 0.7$ & 11.79 \\
LSD 5\% level & & & \\
\hline
\end{tabular}

Harvesting time (140 days later)

\begin{tabular}{|c|c|c|c|c|c|c|c|c|}
\hline $\begin{array}{l}\text { Treat- } \\
\text { ments }\end{array}$ & $\begin{array}{l}\text { Number } \\
\text { of fish }\end{array}$ & $\begin{array}{l}\text { Mean } \\
\text { weight (g) }\end{array}$ & $\begin{array}{l}\text { Biomass } \\
\text { (kg) }\end{array}$ & $\begin{array}{l}\text { Yield } \\
\left(\text { kg. }^{-1}\right)\end{array}$ & $\begin{array}{l}\text { Productivity } \\
\left(\text { kg. } \mathrm{a}^{-1} \cdot \mathrm{y}^{-1}\right)\end{array}$ & $\begin{array}{l}\text { DWG } \\
\left(\text { g.d }{ }^{-1}\right)\end{array}$ & $\begin{array}{l}\text { SR } \\
\text { (\%) }\end{array}$ & $\begin{array}{l}\text { SGR } \\
\left(\% . d^{-1}\right)\end{array}$ \\
\hline T1 & 566 & $31.65 \pm 11$ & 17.90 & $5.14 \pm 1.3^{\mathrm{a}}$ & $12.64 \pm 4.0^{\mathrm{a}}$ & $0.10 \pm 0.03^{\mathrm{a}}$ & $79.82 \pm 7.5^{\mathrm{a}}$ & $0.43 \pm 0.16^{\mathrm{a}}$ \\
\hline T2 & 667 & $29.49 \pm 1.0$ & 19.66 & $4.61 \pm 0.8^{\mathrm{a}}$ & $11.34 \pm 5.4^{\mathrm{a}}$ & $0.14 \pm 0.02^{\mathrm{a}}$ & $85.19 \pm 11.3^{\mathrm{a}}$ & $0.58 \pm 0.06^{b}$ \\
\hline T4 & 747 & $42.30 \pm 4.7$ & 31.60 & $6.35 \pm 1.0^{\mathrm{a}}$ & $18.38 \pm 3.5^{b}$ & $0.15 \pm 0.02^{\mathrm{a}}$ & $93.38 \pm 5.3^{\mathrm{a}}$ & $0.77 \pm 0.07^{\mathrm{c}}$ \\
\hline $\begin{array}{l}\text { LSD } 5 \% \\
\text { level }\end{array}$ & & & & & $*$ & ns & $11.59 \mathrm{~ns}$ & $0.14^{*}$ \\
\hline
\end{tabular}

difference $\mathbf{g}^{-1}=$ oram per day $\% \mathbf{d}^{-1}=$ percentage per day $\mathbf{k g}^{-1} \mathbf{a}^{-1}=\mathrm{kg}$ per are per year $\left(1\right.$ are $\left.=100 \mathrm{~m}^{2}\right)$. Data that have the same superscript letters in the same row are not significantly different at $5 \%$ level of confidence $(\mathrm{p}<0.05)$.

\subsection{Physico-chemical parameters of fishpond water}

\subsubsection{Temperature}

For all treatments, the temperature was low during the dry season $(19.6-24.4$ ${ }^{\circ} \mathrm{C}$ in June, July) and high during the rainy season $\left(20.6-27.8^{\circ} \mathrm{C}\right.$ in March, April and May 2008). The bottom layer always had lower temperatures than the surface, regardless of the time of day (Figure 5). 


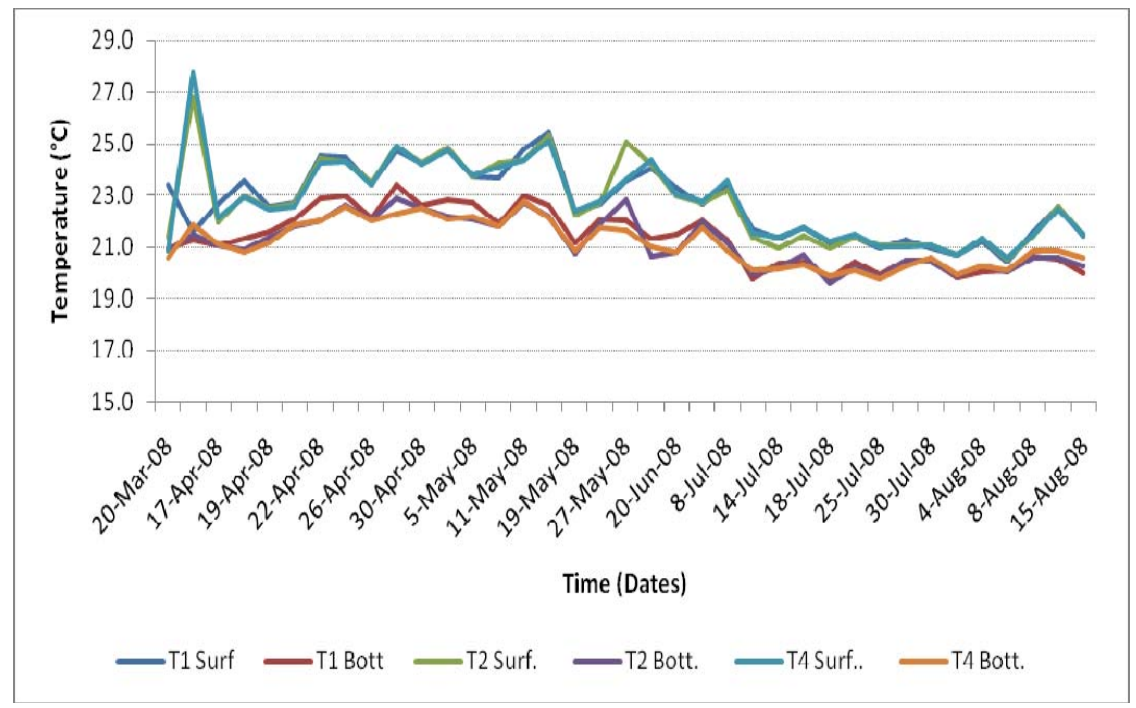

Figure 5: Temperature variation in integrated rabbit-fish production during an experiment with three different rabbit densities on ponds (T1, T2 and T4 are respectively 1, 2 and 4 rabbits per are) (Surface temperature in bluish colour and bottom temperature in reddish colour).

Table 5: Means and standard errors for physico-chemical parameters of water obtained from three different rabbit stocking rates (1, 2, 4 rabbits/are). Values are average of either surface and bottom layers, of three daytime measurements for both surface or bottom layers

\begin{tabular}{|c|c|c|c|}
\hline \multirow[t]{2}{*}{ Parameter } & \multicolumn{3}{|l|}{ Treatments } \\
\hline & T1 & T2 & T4 \\
\hline Temperature $\left({ }^{\circ} \mathrm{C}\right)$ & $22.03 \pm 1.22 \quad(20.09-24.42)$ & $21.97 \pm 1.28 \quad(20.06-24.86)$ & $(20.2-25.26)$ \\
\hline Secchi disk visibility $\left(\mathrm{m}^{-1}\right)$ & $(0.33-0.45)$ & $(0.32-0.41)$ & $(0.23-0.43)$ \\
\hline Conductivity $\left(\mu \mathrm{S} . \mathrm{cm}^{-1}\right)$ & $115.64 \pm 10.24(104.83-128.0)$ & $120.45 \pm 10.06(110.75-132.50)$ & $137.89 \pm 19.96(111.80-155.67)$ \\
\hline $\mathrm{pH}$ & $(5.57-8.81)$ & $(5.0-8.87)$ & $6.69 \pm 0.72 \quad(5.55-9.08)$ \\
\hline Dissolved Oxygen $\left(\mathrm{mg} \cdot \mathrm{L}^{-1}\right)$ & $(1.67-8.91)$ & $(1.59-8.17)$ & $(1.41-10.48)$ \\
\hline $\begin{array}{l}\text { Primary productivity } \\
\left(\mathrm{mgC}^{-2} \mathrm{~m}^{-2} \cdot \mathrm{day}^{-1}\right)\end{array}$ & $286.28 \pm 63.23(178.01-353.22)$ & $321.28 \pm 67.03(238.59-426.82)$ & $292.46 \pm 55.46(243.55-89.05)$ \\
\hline
\end{tabular}

All data are means \pm standard deviation of data collected during the entire period of the experiment. In parenthesis are the minimum and maximum data observed for each treatment (average on 3 replicates). 


\subsubsection{Dissolved Oxygen (DO) and Water transparency (Secchi disk visibility)}

Around $5.0 \mathrm{mg} . \mathrm{l}^{-1}$ of DO were found and reached a maximum of $10.4 \mathrm{mg} . \mathrm{l}^{-1}$ of DO during the day in T4. Morning hours showed the minimum mean concentrations of DO, indicating the night situation for oxygen and these concentrations ranged between 1.41 and $1.67 \mathrm{mg} / \mathrm{l}$. A significant decrease was observed in all treatments but mostly in T4 (Figure 6A) during the experiment's duration. Bottom-pond oxygen remained lower than during the experimental time.

Similar trends were observed for parameters affected by the dynamic of organic matter in ponds. An example of this was the remarkable decrease observed in water transparency (secchi disk visibility) (Figure 6B) and pond primary productivity (Figure 7). Here again, T4, receiving a far greater application of manure, showed lower values in the indicated parameters.
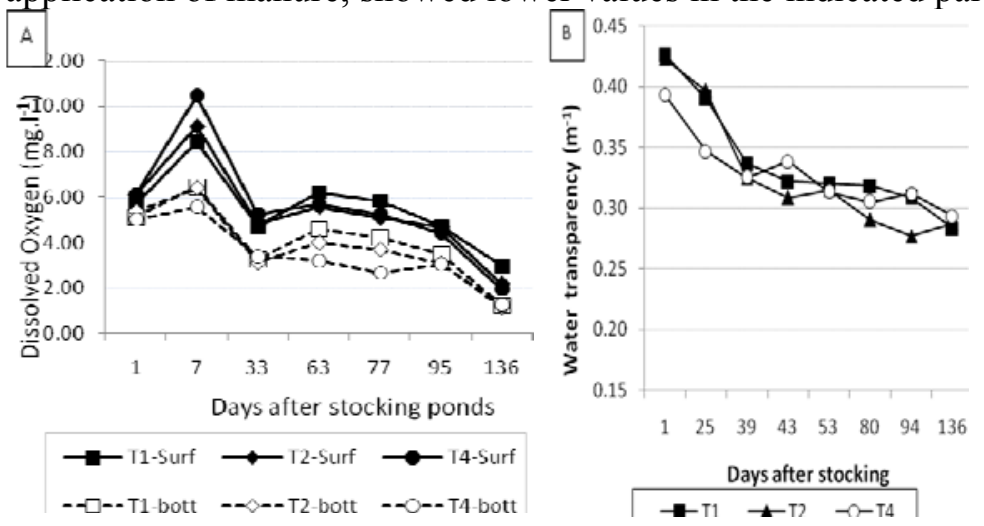

Figure 6: Trends in oxygen variation $[\mathrm{A}]$ and water transparency (Secchi disk visibility $[\mathrm{B}]$ ) in ponds fertilized by droppings from rabbits housed over ponds at three different loads 1, 2 and 4 rabbits/are). Each value is an average of 3 oxygen concentrations from replicates for surface (continued line) and for bottom (discontinuous line) layers and transparency measurements. 


\subsubsection{Primary productivity in fishponds fertilized by rabbits reared above the pond}

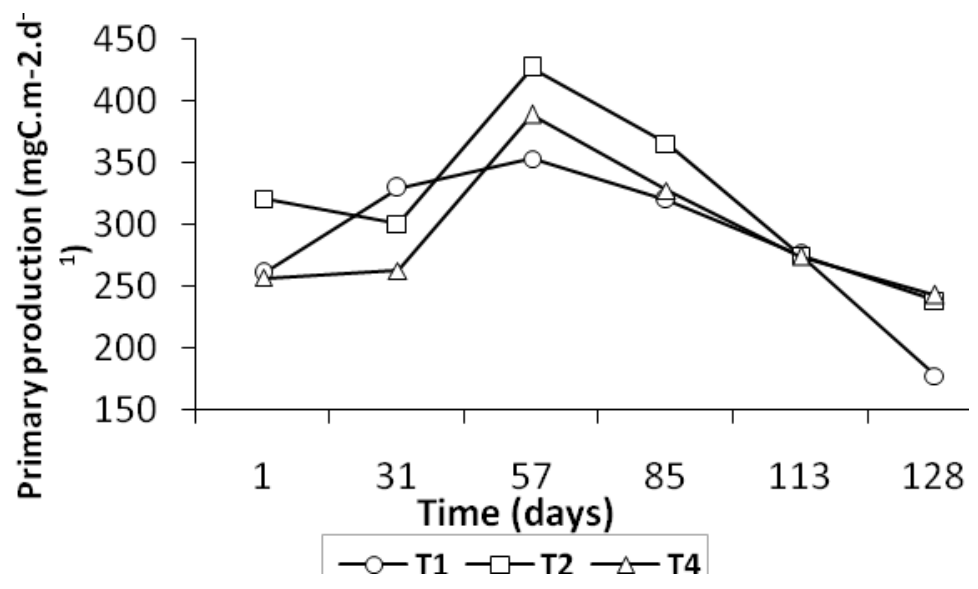

Figure 7: Trend of the primary productivity-change in fish ponds fertilized by rabbit droppings falling from above ponds at three different rabbit densities.

\subsubsection{Total alkalinity and $\mathrm{pH}$ in fish ponds' water}

Total alkalinity $\left(\mathrm{mg} / 1 \mathrm{CaCO}_{3}\right)$ in the pond water did not differ significantly $(\mathrm{P}=0.06)$ between treatments. Slightly higher values were observed in ponds receiving T4 droppings, except at the end of the experiment where a reverse situation was observed but no detectable differences could be seen between treatments. Mean values lay between 43.33 and $72.67 \mathrm{mg} . \mathrm{l}^{-1}$, showing a trend of highly increased total alkalinity over time, seen mostly in T4 (figure 8.A).

In general, single $\mathrm{pH}$ measures in water varied between 5 and 9.08. Daytime mean-values obtained showed that $\mathrm{pH}$ increased at midday and afternoon $\mathrm{pH}$ values were significantly higher $(\mathrm{P}<0.05)$ than those of the morning ones (Figure 8.B). 


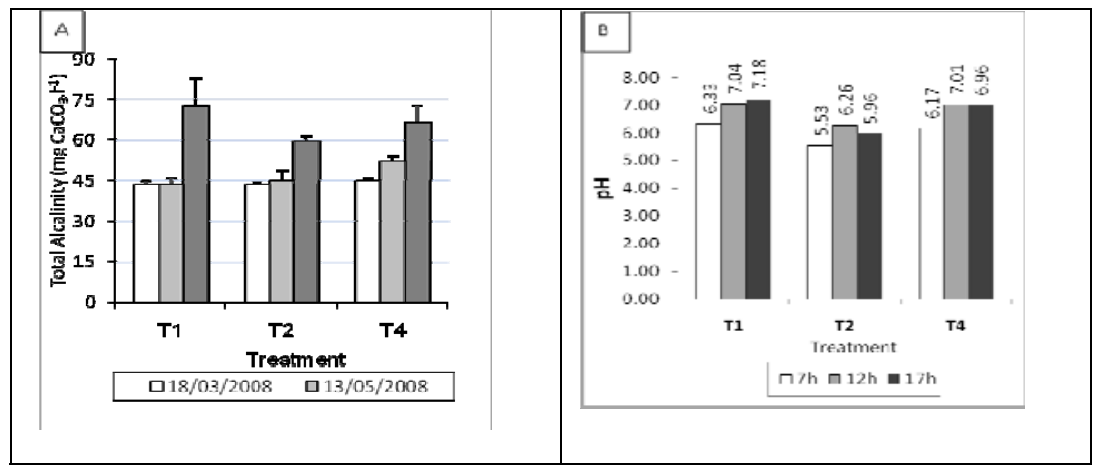

Figure 8: Total alkalinity $[\mathrm{A}]$ at start, mid-term and end of experiment and daytime $\mathrm{pH}$ variation $[\mathrm{B}]$ in fishponds' water fertilized by droppings from rabbits at three different densities over ponds. Each value is an average $\mathrm{pH}$ or total alkalinity of three values being replicates.

\subsubsection{Electrical conductivity}

At the beginning of the experiment, water conductivity values lay between 105 and $122 \mu \mathrm{S} / \mathrm{cm}$ in the three treatments. Three months later, there was a significant increase of conductivity in the treatment where there was the most rabbit dung from (T4) and the same trend was maintained until the end of experiment. The conductivity of water in T1 and T2 didn't differ significantly during the nearly five months of rearing rabbits over fish ponds (Figure 9). Water electrical conductivity in T4 $(158 \pm 2.5 \mu \mathrm{S} / \mathrm{cm})$ was significantly higher than $\mathrm{T} 1(128.7 \pm 1.1 \mu \mathrm{S} / \mathrm{cm})$ and $\mathrm{T} 2(132.5 \pm 0.6 \mu \mathrm{S} / \mathrm{cm})$.

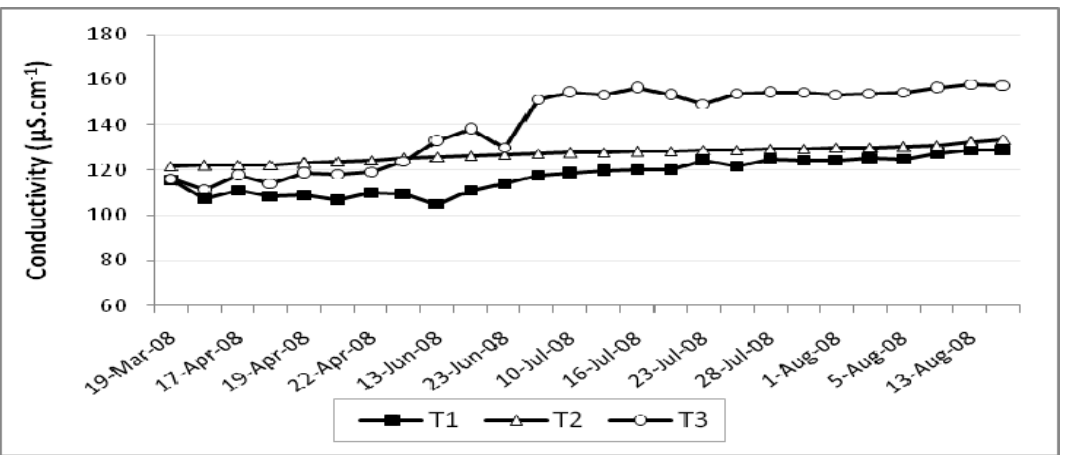

Figure 9: Trend in water electrical conductivity $\left(\mu \mathrm{S} . \mathrm{cm}^{-1}\right)$ in rabbit-fish integrated farming (T1: 1 rabbit/are, T2: 2 rabbits/are, T4: 4 rabbits/are). Each value is an average of 3 replicates and 2 layers in pond (surface and bottom). 


\section{DISCUSSION}

The objective of the research and this paper was to contribute to the optimization of an integrated production system for Rabbit-Fish-Rice, beginning with the search for a rabbit stocking-rate likely to maintain good conditions for fish production in ponds (good condition of fishpond water) while improving rabbit production over fish ponds - living conditions considered harsh by a number of researchers. Although average climactic conditions are reasonable for rabbits in Rwasave marsh, large fluctuations occur frequently, especially during the night where the temperature is always below $12^{\circ} \mathrm{C}$ compared to sometimes being over $28{ }^{\circ} \mathrm{C}$ during the day. These are conditions which cause rabbits to curl up or to stretch out, thereby triggering the outbreak of enteritis, increasing feed intake and decreasing feed conversion rate, which in turn favours the proliferation of pathogens in the gut and the production of lethal toxins (Fayez et al., 1994, Lebas et al., 1996).

Crimella et al. (1991) cited by Yamani and Farghally (1994), reported a 4.2\% weight loss due to high ambient temperatures and 3.8\% weight loss due to 70 $75 \%$ relative humidity.

This study aimed at separately assessing the effect of rabbit droppings on fishgrowth and -production performances following the change induced upon fishpond water quality. This was in order to answer some questions regarding rabbit rearing in a wetland environment and to hence promote its potential role in integrated fish culture.

\section{Rearing rabbits in wetland conditions}

Even though data on rabbits reared in such conditions are very scarce or unavailable in literature, this study showed that marsh weather conditions did not prevent rabbits from surviving $\left(100-95 \%\right.$ SR) and growing $\left(11.5\right.$ to 9 g.d $^{-1}$ DWG). This finding is encouraging for the rearing of rabbits over ponds. Similar observations were reported by (Matsiko, 2004) who noted up to 13.3 g. $\mathrm{d}^{-1}$ of DWG and high survival rates of rabbits under wetland conditions and advised greater care for young rabbits during the high-moisture period (rainy season). In addition, (Lebas et al., 1996), pointed out a failure in rabbit husbandry caused by the aggressiveness of either males or females within a group that leads to a decrease in food intake. This explains why better growth and performance were observed in $\mathrm{T} 1$ for all measured parameters (Mean weight, DWG, SGR, and SR, (Table 2) in which the experiment operated only 
at low densities so there was less or no stress at all. Moreover, rabbits were fed on forage ad libitum as this is indicated to be the best feeding strategy for sustainable rabbit husbandry (Lukefahr, 2007). This author strongly recommends forage because rabbits have the ability to utilize various byproducts, and they are 2.5 to 4 times more efficient in extracting proteins from forage than sheep and beef cattle (Samkol and Lukefahr, 2008).

\section{Nutrients ( $N$ and $P$ forms) in ponds after fertilization by rabbit droppings}

Rabbit manure dropped continuously into fish ponds supplies nutrients. The quantity and quality of nutrient consumed in animal diets will primarily reflect the composition and quality of nutrients available (Van Horn, 1998). Given the fact that rabbit manure is ten times higher in nitrogen than that of cow dung, rabbit manure sustains better plankton production by releasing nutrients gradually into water (Kumar and Ayyapan, 1998). In this integrated system, fishpond water receiving droppings from rabbits was enriched continuously mainly in nitrogen-nutrients and phosphorus-nutrients after bacterial decomposition in water. Most nutrient concentrations increased significantly with time in all treatments except nitrates-nitrogen. This indicated the positive role that rabbit droppings play in fertilizing fish ponds, as previously noted by several authors (Breine et al., 1996, Franco, 1991, Kumar and Ayyapan, 1998, Little and Edwards, 2001). None of the treatments resulted in any nutrient increasing to maximum allowed concentrations for the protection of fish life. (Breine et al., 1996) reported little or no effect on ammonia and nitrite concentrations. These remained lower than the limit for harmful concentrations for $O$. niloticus. It should be noted, however, that ammonia-nitrogen increased significantly in T4 as did the total alkalinity that supported microbial activity which was most important in T4. The same pattern was observed for nitritenitrogen but its concentrations did not rise above $1.0 \mathrm{mg} / \mathrm{l}$, far lower than the $5 \mathrm{mg} / 1$ considered to be lethal for Nile tilapia (Losordo, 1997). Very high nitrites are reported in ponds where $\mathrm{pH}$ tends to be acidic due to acidic soil or an accumulation of humus preventing bacteria from helping organic matter to decompose. In Rwasave marsh, soil $\mathrm{pH}$ is slightly acidic $(4.5-6.5)$ but that of ponds has changed due to fertilization over a long period.

Mean nitrates-nitrogen were relatively highly concentrated $(0.76,1.46$, and $2.72 \mathrm{mg} / 1$ for T1, T2, and T4 respectively) and decreased significantly with time in the study's rabbit-fish system compared to $0.16,0.12,0.39 \mathrm{mg} / 1$ when 
Rwasave ponds were fertilized with cow dung mixed with compost, with green grass and with compost respectively by (Rwangano, 1990) and $0.12,0.11 \mathrm{mg} / \mathrm{l}$ (Tepe and Boyd, 2002) when treating ponds with ammonium sulfate and sodium nitrate. This indicates that rabbits above ponds did not negatively influence the quality of fishpond water on the one hand but it did result in low primary productivity on the other hand, which may have affected fish growthperformance. Concentrations of soluble reactive phosphates were quite similar to phosphorus in ponds fertilized by green grass and chemical fertilizer (Tepe and Boyd, 2002) which could not produce enough phytoplankton bloom. Many authors agree that soluble reactive phosphorus-only treatments are adequate for good fish production. They confirmed that nitrogen fertilization was not as important as phosphorus fertilization (Swingle et al., 1965, Murad and Boyd., 1987, cited by (Tepe and Boyd, 2002).

\section{Primary productivity}

Results obtained for primary productivity in ponds fertilized by rabbit droppings, were lower than previously found in ponds receiving dried rabbit dung from a remote location. The primary productivity in this study's ponds were 286,28 and $321,28 \mathrm{mgC} . \mathrm{m}^{-2}$. day ${ }^{-1}$ compared to $0.69,0.75$ and $0.70 \mathrm{~g} \mathrm{C.m}$ ${ }^{2}$.day ${ }^{-1}$ (Franco, 1991) for the control, $50 \mathrm{~kg}$ and $75 \mathrm{~kg}$ rabbit dung loads, and to 0.93 and $1.3 \mathrm{~g} \mathrm{C} . \mathrm{m}^{-2}$. day ${ }^{-1}$ reported for a tropical pond system by TeichertCoddington, 1991). Physico-chemical parameters measured during this study, such as $\mathrm{pH}>5$, did not show limitations to primary productivity in general. The observed trend of declining transparency could normally meet an increasing trend in primary production but results suggest that there may be a source of turbidity other than phytoplankton responsible for the decrease in transparency. Water alkalinity was relatively high enough $\left(45-73 \mathrm{mgCaCO}_{3} / \mathrm{l}\right)$ to increase primary productivity if we refer to McNabb et al, (1989), Boyd (1979) quoted by (Rwangano, 1990). These authors reported an increasing phytoplankton production in fertilized ponds of $20-60 \mathrm{mgCaCO}_{3} / 1$, while no correlation between total alkalinity and algal productivity was observed in ponds with alkalinity values of $20-120 \mathrm{mgCaCO}_{3} /$. Considering the history of used ponds, suspended inorganic particulates and clay in suspension might have raised pond turbidity and blocked sun radiation from boosting algal photosynthesis (Boyd and Tucker, 1998, Tepe and Boyd, 2002). These observations support the findings that none of the three treatments with rabbit droppings in this study have reached a high level of plankton production. 


\section{Rabbit droppings and O.niloticus production performance}

Multiple regression analysis on fish weight and rearing days confirms the results on mean weight-increase over time, showing significant differences between treatments $(\mathrm{P}=0.000,0.001$ and 0.003 respectively for $\mathrm{T} 4, \mathrm{~T} 2$, and T1), T4 having the steepest slope. Taken together, the three rabbit load-rates explain the variance in fish weight-growth of about $91 \%$. These results on fish (growth and production) were in the same range as other reported growth for tilapia from fertilized ponds with duck, chicken and goat manure in China, Bangladesh and India (Quazi and Huque, 1991).

In general, growth and production assessed for $O$. niloticus during this study are low but promising after only approximately five months since no supplemental feeds were supplied. Reports on growth (42.3 g mean weight), SGR $\left(0.77 \%\right.$.day $\left.{ }^{-1}\right), 93 \%$ survival rate, a net fish production $(18.38 \mathrm{~kg}$.are ${ }^{1}$.year ${ }^{-1}$ ) are encouraging especially for rural resource-poor farmers. However, specific growth with rabbit droppings fertilization was slightly higher than that for fertilization with cow dung, grass and compost and also higher than that for biodigestor effluent from cow and rabbit dung (Mahadevaswamy and Venkataraman, 1988). This is not surprising, since rabbit manure is more concentrated in phosphorus and nitrogen components than other animal manure (Lebas et al., 1996) and its nitrogen content is reported to be 10 times higher than that of cow dung (Kumar and Ayyapan, 1998). Fish growth- and production-performance are always attributed to the farming environment, which includes the biological and physico-chemical quality of the medium. Parameters discussed above have led to better Nile tilapia (O. niloticus) growth, linked to the relatively high number of rabbits in this experiment. Many studies reported a close relationship between net fish-yield and chlorophyll $a$ for primary productivity in fertilized ponds as well as in a fish feeding regime, (Rwangano, 1990) quoting Moriarty, 1973; (Boyd, 1979, Gross et al., 1999, Little and Edwards, 2003). The performance reported here can be considered the lowest possible because the rabbit loading-rate didn't bring the ponds to the high level of primary production, alkalinity, and phosphatecontent that favour filter-feeder fish like Nile tilapia (O. niloticus). This highlights the need to further studies on rabbit loading-rates to clearly establish the effect of different rates on the quality and management of fish ponds. 


\section{Physico-chemical parameters of fish pond water as affected by rabbit droppings}

When rabbit droppings have decomposed in fish ponds, they enrich water with nitrogen which exists in the form of ammonia, nitrites, and nitrates. The nitrogen in water favours microbial activities that result in a change in the whole physico-chemical composition of the fishpond water. Temperature, water transparency, dissolved oxygen, and $\mathrm{pH}$ concentrations obtained for these parameters (Table 5) remained in the range required for sustainable fish production. No significant differences were recorded among treatments for all these physico-chemical parameters. However, mean temperatures were low $\left( \pm 22^{\circ} \mathrm{C}\right)$ and showed a fluctuation from $20.0^{\circ} \mathrm{C}$ to $25.3^{\circ} \mathrm{C}$, the highest temperature being in the treatment with the highest rabbit stocking-rate. The lack of differences here indicates that stocking rates, used as a treatment, influence water quality similarly. This suggests that further research is needed on optimization of suitable rabbit stocking densities.

Mean dissolved oxygen concentrations averaged $5 \mathrm{mg} / 1$ in all treatments but the minimum recorded in each one shows a trend of eutrophication: 1.67, 1.59 and $1.41 \mathrm{mg} / \mathrm{l}$ for respectively $\mathrm{T} 1, \mathrm{~T} 2$, and $\mathrm{T} 4$ are under the minimum acceptable levels of dissolved oxygen concentrations set at $3 \mathrm{mg} / \mathrm{l}$ for fish (Mmochi et al., 2002). Lower DO concentrations were measured during morning hours, indicating microbial activity that consumes oxygen during the night while daytime DO averaged 8 to $10 \mathrm{mg} / 1$ due to photosynthesis by phytoplankton (Mmochi et al., 2002, Tepe and Boyd, 2002, Boyd and Queiroz, 2001). Ponds getting an increasing quantity of organic matter entertain continuous degradation reactions that decrease concentration of dissolved oxygen and increase available dissolved nutrients in ponds (Tepe and Boyd, 2002, Tucker and Hargreaves, 2003).

Mean $\mathrm{pH}$ obtained, ranged between 6.5 and 6.7, which is within optimum limits for fish growth but it increased during the day (i.e. $\mathrm{pH}=9.1$ in $\mathrm{T} 4$, Figure 8.B), probably due to phytoplankton that utilize and consume carbon dioxide for photosynthesis. Morning $\mathrm{pH}$ was relatively low due to respiration of living organisms during the night discharging carbon dioxide in the ponds. (Boyd and Queiroz, 2001, Franco, 1991, Mmochi et al., 2002) pointed out a remarkable trend of a decrease in dissolved oxygen relative to fertilizing time. $\mathrm{pH}$ fluctuations also explain what happens regarding dissolved oxygen in ponds receiving rabbit dung when morning DO levels were very low in ponds with a 
high density of rabbits above them. However, neither $\mathrm{pH}$ nor DO levels in the tested rabbit stocking rates reached harmful values that would require preventative measures.

\section{CONCLUSION}

The primary focus of this study and also of the proposed integrated rabbit-fishrice system was to investigate the influence of rabbit droppings on the quality of water and on fish growth performance. After almost five months rearing rabbits housed over fish ponds, rabbit dejections dropped directly from rabbits affected the quality of water establishing a better environment for fish $(O$. niloticus). Unexpected results for some physico-chemical patterns showed, however, that certain set treatments were not able to be fully explained.

Further experiments should be undertaken, in order to optimize load-rates that can improve $\mathrm{pH}$ and dissolved oxygen concentrations, so as to avoid limiting the nitrifying process and total alkalinity, thus ensuring a better use of carbon by primary producers in ponds. Nevertheless, higher rabbit-densities need to be tested, as the highest in the present study was just starting to show promising results in terms of providing conditions that led to fish productivity very close to those obtained with chicken, pig, green grass, duck and goat manure.

Even though productivity is still lower than that of intensive aquaculture using high quality concentrates, this Integrated Agriculture Aquaculture system (rabbit-fish system) can be applied successfully by rural small scale fish farmers rather than using very expensive and unaffordable inputs (feed concentrates, duck and poultry manure). In this way, the proposed rabbit-fish system is suited to reducing the expense of concentrated feed and providing a more balanced natural diet to filter feeder fish like Tilapia, while maintaining a safe environment and thus ensuring the sustainability of production.

\section{Acknowledgments}

This work is the first part of an ongoing PhD research funded by the Nile Basin Initiative (NBI-ATP) to whom I would like to convey my gratitude for assistance. Authors also acknowledge the devotion showed by the team of Rwasave fish farming station during the experiment, and thank very much Mrs A. Zaverdinos for the proof reading of the manuscript. 


\section{REFERENCES}

1. AZIM, M., VERDEGEM, M., RAHMAN, M., WAHAB, M., VAN DAM, A. \& BEVERIDGE, M. 2002. Evaluation of polyculture of Indian major carps in periphyton-based ponds. Aquaculture, 213, 131-149.

2. BOYD, C. 1979. Water quality in warmwater fish ponds, Alabama, Alabama Agricultural Experiment Station. Auburn University

3. BOYD, C. \& TUCKER, C. 1998. Pond aquaculture water quality management, Alabama, Kluwer Academic Publishers.

4. BOYD, C. E. \& QUEIROZ, J. F. 2001. Nitrogen, Phosphorus loads vary by system. The Advocate / Global Aquaculture Alliance USA, 84-86.

5. BREINE, J., TEUGELS, G. \& OLLEVIER, F. 1995. Résultats préliminaires de la pisciculture intégrée à la station de recherche piscicole de Foumban, Cameroun In: MICHA, J. C. \& SYMOENS, eds. l'Aménagement des écosystèmes agro-piscicoles d'eau douce en milieu tropical 16-19 mai 1995, 1995, Bruxelles Belgique. 413-418.

6. BREINE, J., TEUGELS, G., PODOOR, N. \& OLLEVIER, F. 1996. First data on rabbit dung as a water fertilizer in tropical fish culture and its effect on the growth of Oreochromis niloticus (Teleostei, Cichlidae). Hydrobiologia, 321, 101-107.

7. DAUTA, A. \& CAPBLANCQ, J. 1999. Photosynthesis simulator PSS2000. Toulouse France: C.E.S.A.C / CNRS - Université Paul Sabatier.

8. DESCY, J. P. 1989. Manuel pratique des techniques d'analyse de l'eau. Analyses physico-chimiques. Namur Belgique: FUNDP- Namur.

9. FAYEZ, I. M., ALNAIMI, A. \& HABEEB, M. 1994. Thermoregulation in rabbits Cahiers Options Méditerrannéennes; vol 8 CIHEAM - IAMZ, $p$. 33-41 Cairo (Egypt).

10. FRANCO, L. 1991. Nile Tilapia production in tropical microcosms fertilized with rabbit excreta. MSc thesis, Oregon State University.

11. FRANSON, M., CLESCERI, L., GREENBERG, A. \& EATON, A. 1985. Standard methods for the examination of water and wastewater, American Public Health Association Washington, DC.

12. GROSS, A., BOYD, C. E. \& LOVELL, R. 1999. Effects of feed protein concentration and feeding rate combinations on quality of pond water and effluent in Channel catfish culture. . The Israeli journal of Aquaculture Bamidgeh, 51, 47-57.

13. JAMU, D. \& PIEDRAHITA, R. 2002. An organic matter and nitrogen dynamics model for the ecological analysis of integrated aquaculture/ 
agriculture systems: I. model development and calibration. Environmental Modelling \& Software, 17, 571-582.

14. KAPETSKY, J. 1994. A strategic assessment of warm-water fish farming potential in Africa, Food \& Agriculture Org.

15. KUMAR, K. \& AYYAPAN, S. 1998. Integrated aquaculture in Eastern India, Working paper 5, . Purulia India: Institute of fresh aquaculture.

16. LEBAS, F., COUDERT, P., ROCHAMBEAU, H. \& THÉBAULT, R. 1996. Le lapin: Elevage et pathologie (nouvelle version revisitée), Rome, Collection FAO Production et Santé animales.

17. LÉONARD, V. \& KANANGIRE, C. K. 1998. Recueil de Methodes d'analyses physico-chimiques de l'eau, des sols et des aliments. Butare Rwanda: Université Nationale du Rwanda / Facultés Universitaires Notre Dame de la Paix de Namur.

18. LITTLE, D. \& EDWARDS, P. 2003. Integrated livestock-fish farming systems, Rome, FAO Viale terme di Carcalla.

19. LITTLE, D. C. \& EDWARDS, P. 2001. Integrated Livestock-Fish Farming Systems: The Asian Experience and its Relevance for other Regions (Draft). PhD PhD thesis, Asian Institute of Technology.

20. LOSORDO, T. 1997. Tilapia culture in intensive recirculating systems. Tilapia aquaculture in the Americas, 1, 185-211.

21. LUKEFAHR, S. 2007. Strategies for the development of small-and medium-scale rabbit farming in South-East Asia. Livestock Research for Rural Development, 19.

22. MAHADEVASWAMY, M. \& VENKATARAMAN, L. 1988. Integrated utilization of rabbit droppings for biogas and fish production. Biological Wastes, 25, 249-256.

23. MATSIKO, S. D. 2004. Optimization of the rabbit charge in the fish (Oreochromis niloticus)-rabbit integration in Rwanda. MSc MSc research, Gent University.

24. MCCROSCKEY, R. 2001. Integration of rabbit production into populated areas, especially in hot climates. pan-am.uniserve.com, 6, 18-20.

25. MICHA, J. 2001. Systèmes d'élevages intégrés en zones humides tropicales In: KANANGIRE, C. K., MICHA, J.-C. \& GASHAGAZA, J.-B. M., eds. Aménagement des marais au Rwanda, 5-7June 2001, 2001, Butare-Rwanda. Presse Universitaire de Namur-Belgique, 118. 
26. MINECOFIN 2002. The Government of Rwanda: Poverty Reduction Strategy Paper. In: EDPRS, M. O. F. A. E. P. (ed.). Kigali Rwanda: MINECOFIN.

27. MMOCHI, A., DUBI, A., MAMBOYA, F. \& MWANDYA, A. 2002. Effects of Fish Culture on Water Quality of an Integrated Mariculture Pond System.

28. QUAZI, M. \& HUQUE, Q. 1991. Integrated Livestock-fish farming: Bangladesh perspective, . In: Aquaculture and consumer Protection 16 -20 December 1991, 1991, . Rome.

29. RWANGANO, F. 1990. Interactions of organic input types and water quality on the production of Oreochromis niloticus(Linnaeus, 1757) in Rwandan ponds. Oregon State University.

30. SAMKOL, P. \& LUKEFAHR, S. 2008. A Challenging Role for Organic Rabbit Production Towards Poverty Alleviation in South East Asia. In: 9th World Rabbit Congress June 10-13, 2008, Verona - Italy. World Rabbit Science Association, 1479 - 1497.

31. TEPE, Y. \& BOYD, C. E. 2002. Nitrogen Fertilization of Golden Shine Ponds. North American Journal of Aquaculture American Fisheries Society - USA, 64, 284 - 289.

32. TUCKER, C. \& HARGREAVES, J. 2003. Management of effluents from channel catfish (Ictalurus punctatus) embankment ponds in the southeastern United States. Aquaculture, 226, 5-21.

33. VAN DAM, A., KAGGWA, R. \& KIPKEMBOI, J. 2006. Integrated pond aquaculture in Lake Victoria wetlands. Integrated irrigation and aquaculture in West Africa: concepts, practices and potential, 129.

34. VAN HORN, H. 1998. Factors affecting manure quantity, quality, and use. In: The Mid-South Ruminant Nutrition Conference, May 7-8,, 1998, Dallas-Ft Warth. Texas Animal Nutrition Council, 9-20.

35. VAN VLEET, J. 1991. Raising Rabbits over Fish Ponds. In: VEVERICA, K. L., ed. Third conference on the Culture of Tilapias at High Elevations in Africa, April, 1997, 1991, Rwasave Fish Farming Research StationRwanda. Auburn University: International Center for Aquaculture and Aquatic Environments, 26.

36. YAMANI, K. \& FARGHALLY, H. 1994. Adaptability of rabbits to the hot climate. Egyptian Journal of Rabbit Science (Egypt), 65-69. 